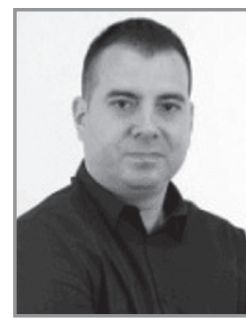

\title{
Vuk BEVANDA
}

Faculty of Social Sciences

Belgrade

Received: 12. 3. 2021. $\square$

CONTACT: vuk.bevanda@fdn.edu.rs

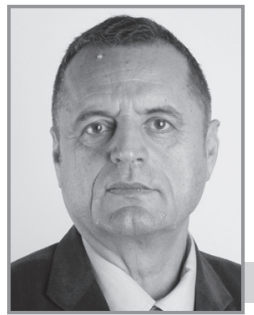

\section{Rajko MACURA}

Banja Luka College

Banja Luka

CONTACT: macurarajko@gmail.com

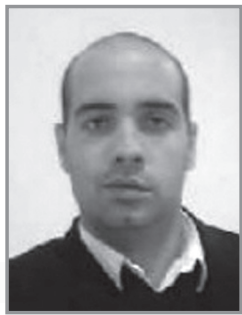

\section{Andrija BLANUŠA}

Faculty of Social Sciences

Belgrade

CONTACT: andrija.blanusa@fdn.edu.rs

\section{THE ROLE AND IMPORTANCE OF BUSINESS ECONOMICS IN THE DEVELOPMENT OF MODERN COMPANIES AND ORGANIZATIONS}

Abstract: Business economics belongs to the group of economic sciences. Business economics is a scientific field that deals with the business of a company in conditions of limited resources and market laws. It is a complex comprehensive discipline that studies economic conditions, economic processes and economic relations within a company. Within the business economics, a qualitative and quantitative analysis of all economic phenomena, categories and relations in the company and its wider economic and functional environment is performed. The paper studies the direct and indirect impact of business economics in the development of modern companies and organizations.

Keywords: BUSINESS ECONOMICS, COMPANY, BUSINESS OPERATIONS, ORGANIZATION, ECONOMY, MANAGEMENT. 


\section{The subject of study of business economics}

There are numerous theoretical approaches to business economics as a scientific and teaching discipline. Among the many authors who have studied this area, we would like to single out the following:

"Business economics is a field of applied economics that studies the financial, organizational, market-related, and environmental issues faced by corporations. Business economics assesses certain factors impacting corporations - business organization, management, expansion, and strategy - using economic theory and quantitative methods. Research topics in the field of business economics might include how and why corporations expand, the impact of entrepreneurs, interactions among corporations, and the role of governments in regulation." (Banton, 2020)

As regards the scope of business economics, no uniformity of views exists among various authors. The scope of business economics (micro and macro variety) is a wider one since it

"uses the logic of economics, mathematics, and statistics to provide effective ways of thinking about business decision problems." (Nageshwar, 2021)

"Business economics studies economic conditions, processes and relations within the basic economic unit - the company as a business entity. Within this discipline, a qualitative and quantitative analysis of all economic phenomena, categories and relations of the company and its economic environment is performed. The goals and methods of business economics are aimed at finding optimal solutions for the realization of the set tasks of the company, in conditions of limited resources and market competition." (Živković, Dragičević-Radičević, llić, Bevanda, 2007: 3)

"Within the discipline business economics, the totality of economic interests, i.e. goals of the company and its relevant environment, their qualitative and quantitative properties and mutual relations of components, i.e. subsystems are included. It studies the efficiency and effectiveness of the functioning and development of the company as a business unit and business entity." (Živković, Dragičević-Radičević, Ilić, Bevanda, 2007: 3)

Business economics, as a scientific discipline, includes economic flows and events in the company. It studies the state and changes in the business phases of the company, the principles and laws in the course of its reproduction. 
Rajko MACURA

Banja Luka College

Banja Luka
Andrija BLANUŠA

Faculty of Social Sciences

Belgrade

Business economics, in terms of the above, studies the economic laws and principles of the process of work and business of the company, through the investment components and business results of the company. It also studies the relationships between results and investments, as well as the factors that determine changes in company's business activities and development.

Investments are made in the form of spending the components of the company (equipment, materials, labor force) and in the form of engaging funds and labor force. The study of costs and their dynamics is an important area of business economics.

The business results of the company are expressed in the form of physical product and service as use values, realized value and profit, as the final financial result. The goal of the company is to achieve the highest possible result, with the least possible spending and engagement of material components (funds) and human labor.

Numerous internal and external factors affect investments and results, with different, often opposite effects. The influence and interactions of different factors are also the subject of the study of business economics. The most important factors relate to: technology, market, state measures in the field of economic policy. Internal factors refer to the organization and mutual relations of employees, their motivation, organizational behavior and more.

The company has different relationships between results and investments, which is a consequence of the influence of certain factors in the dynamics of time, different conditions and methods of organizing the process of reproduction of the company, and its market position. The relationship between results and investments is subject to monitoring and study within the business dynamics of the company.

The business of a company is studied primarily through the ratio of the value of the achieved results and the value of the investments made in the creation of those values. These values are expressed at appropriate and comparable prices.

The survival and development of the company as its basic goals will be possible only if it covers or compensates the spent values with the achieved results. The achieved business results must be verified through the market mechanism of the company's business operations. 

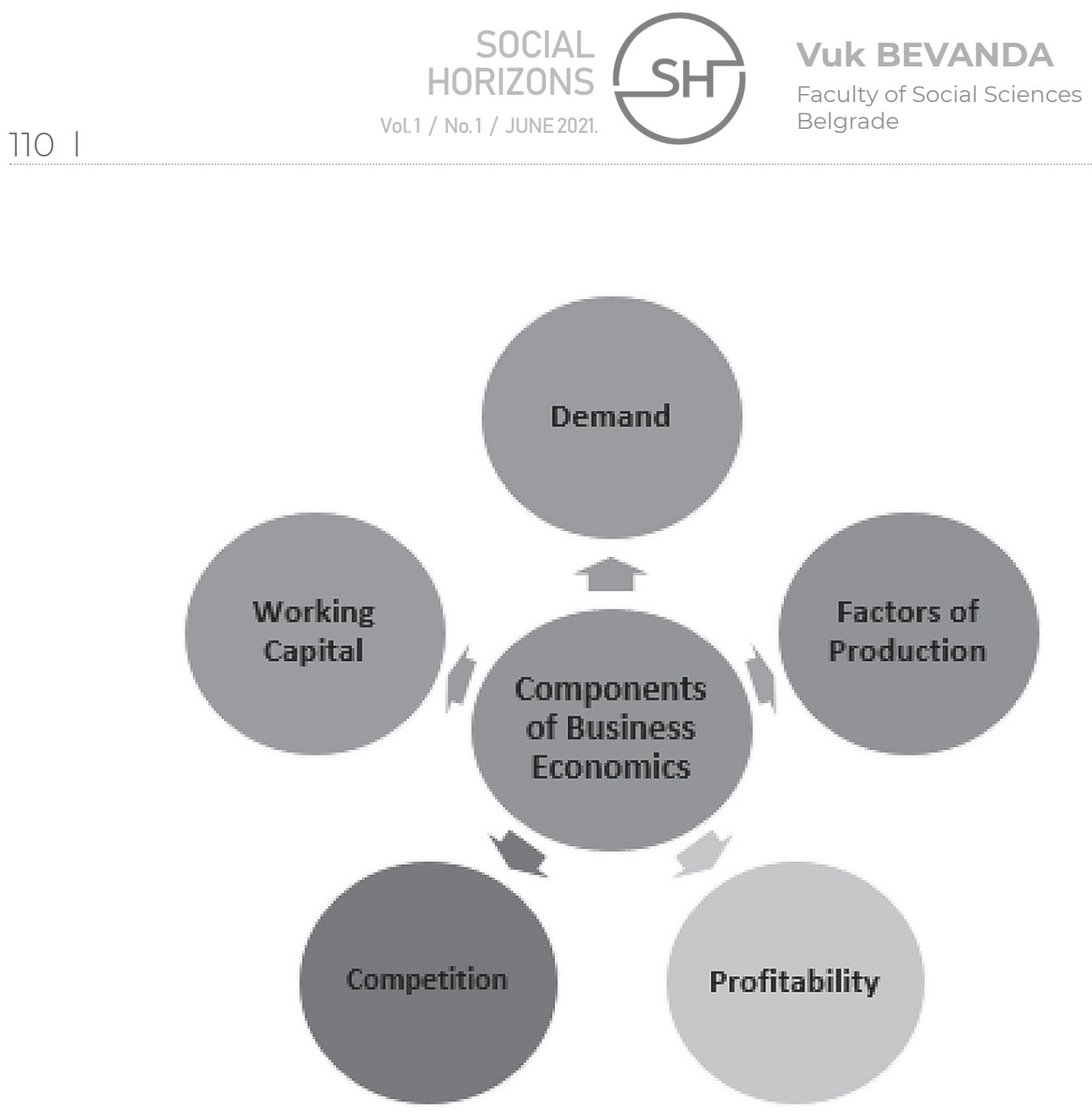

Picture 1: Components of Business Economics*

Business economics studies and develops its own methods, the application of which ensures the business success of the company and the continuity of its development. It discovers and develops new knowledge and laws in the business of the company and its reproduction.

Business economics also studies and elaborates the economic principles of the company's business, which ensure its efficiency and effectiveness. These are, above all, the principles of productivity, economizing and profitability of business. The application of these and other principles ensures a favorable relationship between results and investment, and thus survival and development as the basic target functions of the company. 
Rajko MACURA

Banja Luka College

Banja Luka
Andrija BLANUŠA

Faculty of Social Sciences

Belgrade

Business economics studies general economic laws in the processes of work and business in achieving the results of work processes. This includes phenomena and all processes that occur in the company itself, as well as in the company's relations with the market and other economic entities and institutions with which the company is business and organizationally connected.

Business economics as a practical discipline encompasses the economic reality of the company, i.e. the overall events and changes in the life cycle of the company: its organization, components and human resources.

Business economics as a science and business economics as a practical activity and a set of numerous activities can be developed independently of each other. However, the success and development of both depend on their interconnectedness. Science should start from practical experiences and achievements, and its purpose is to serve practice. On the other hand, the practice will not be successful if it does not rely on new and available scientific knowledge and methods.

In addition to business economics as an economic discipline that studies general knowledge that applies to all companies, there are also special disciplines of business economics that relate to the types of activities, economic branches or functions that the company performs.

Subdisciplines of business economics can be classified into (Živković, Ilić, Bevanda, 2014: 31-32):

- economics of industrial companies;

- economics of agricultural companies;

- economics of commercial companies;

- economics of catering companies;

- economics of construction companies, and more.

These, narrower disciplines of business economics, study the specifics of companies in these economic activities and branches in order to ensure their development and increase business efficiency.

From the point of view of functions in the company, we can study separately: the economics of procurement, production, sales, planning, accounting, etc. - as special, segmental scientific disciplines of business economics. 


\section{Historic development of business economics}

Business economics is a relatively young scientific discipline. In its historical development, it has developed more as a result of other related scientific disciplines and economic practice, and less as a result of its own research.

The first significant contributions to the knowledge of the company were made by medieval merchants in their "trade books". They contained useful instructions, conclusions and views gained from long experience.

Leonardo da Vinci and Rene Descartes also indirectly contributed to the business economics through research in the field of mathematics and construction techniques. (Kukoleča, 1965: 18-25)

The first traces of the science of business economics can be found at the end of the 15th century. In the work of Luca Pacioli "Handbook for Arithmetic, Geometry, Scales and Relations", published in 1494, the technique of double-entry bookkeeping was published for the first time, as the first general knowledge about the economics of trade, i.e. trade companies.

From then, until the next four centuries, books and papers on methods and techniques of bookkeeping would be at the same time the most reliable sources that contain sporadic, but still somewhat general knowledge about the economy of trade and trade companies. (Kukoleča, 1965: 26)

The foundations of business economics were laid in Germany in the first decades of the 20th century. At that time, significant works from the field of bookkeeping and balance sheet accounting of the German authors Schmalenbach, Niklisch and Mellerowicz were published.

Although they put the principles of efficiency of accounting control, cost planning and balance sheet planning in the foreground, the contribution of these authors to the development of business economics as a science in its initial phase is undoubted (E. Schmalenbach: "Dinamische Bilanz, Grundlagen des Selbstkostenrechnung und Kontenzahmen”; H. Nicklish: „Die Betriebswirtschaft”; K. Mellerowicz: "Allgemeine Betriebswirtschaftslehre"). In the works of these authors, the orientation is expressed on the economic content of the company, and less on the methods and techniques of research of economic phenomena.

Business economics as a scientific discipline therefore has its roots in the bookkeeping and balance sheet theories of German authors. Therefore, many findings and theoretical conclusions of business economics bear the stamp of 
Rajko MACURA

Banja Luka College

Banja Luka
Andrija BLANUŠA

Faculty of Social Sciences

Belgrade

bookkeeping-balance sheet categories and concepts. In these studies, the situation and balance sheets in the company are observed more, and the behavior of people and their relationships within the company are less observed.

The first scientific works of domestic authors in the field of business economics and balance sheet analysis are also strongly influenced by the mentioned and other German authors. They refer to research on the categories of cost interdependence, fixed costs, company finances, balance sheets, chart of accounts, relationships between certain types of costs and the like.

The characteristic of these researches is the absence of a more complex systemic approach to the company's economy. The elements of investment and results, engagement and spending of funds in the unique process of reproduction of the company are almost not studied, but mostly, and partially: production, turnover, financing, balance sheets, costs and the like.

Since business economics as a scientific discipline has its roots in bookkeeping and balance sheet theories, its conclusions and research bear the stamp of these bookkeeping and balance sheet concepts, as already mentioned. They are based on observing the "image of the company" instead of its behavior in real life. Such an approach produces, in a series of time sections, a series of static images of the quality of the company's economy, strictly integrated into balance sheet forms - instead of a constant and direct view of its dynamics. This is not enough from the point of view of business economics as a scientific discipline that should provide a theoretical basis for successful and operational management of company's economy.

The contribution of the American school is significant in the development of business economics as a scientific-teaching discipline, i.e. in the study of the economic content of the company's activities. As the cradle of scientific management in the development of science in this field, American authors were oriented mainly to various methods and techniques of business and the practical application of these methods in the company.

The influence of American authors on the development of theoretical thought in this area in Europe is becoming more pronounced, both through schools in which operational management personnel are trained, and through the organizational practice of joint ventures through international corporations.

The emergence of methodological scientific disciplines, such as operational research, game theory, statistical analysis and the like, the application of which is focused primarily on companies, also contributes to the faster development of business economics. These new methods promised, with their application and results, faster progress in researching the problems of business economics.

The application of new methods contributed to a turn in the business economics in the 60 s of the twentieth century, directing research to methods, and through them to the economic content of life in the company. 
This direction of research is characterized by (Živković, Ilić, Bevanda, 2014: 21):

1. developing numerous methods and techniques of management and decisionmaking in the company;

2. market aspect and characteristics of the business economics;

3. introduction and elaboration of operational research methods in the decisionmaking process of the company;

4. cybernation of a company as an organizational system.

In the study of economic and methodological issues of the company (enterprise, corporation), management has played a special role in the development so far. Here, too, the focus of study and research rested on the development of new techniques and methods of business. At the same time, the goals and economic content are included only as a socio-economic precondition for the application of methods, without their deeper analysis, connection and interdependence.

New decision-making methods in management have been attractive from the point of view of application and acceptance by management teams as a very successful management instrument. Decision theory and "game theory" developed very quickly as scientific and teaching disciplines - pushing the subject itself, i.e. the company and its technological, organizational and work processes into the background.

This quantitative approach has slowed and pushed into the background the development of the business economics. The economic content of events in the company was studied from a special angle of market dynamics. By applying mathematical-graphic methods, the analysis of the dynamics of economic activities and the results of the company is performed. Market factors have a predominant influence on the sale of products in modern conditions, so their monitoring and study has become a significant subject and content of the business economics.

On this basis, marketing also appears, as a separate discipline, which in a very short period of time develops and improves the skill of trading in America and Europe. Marketing is becoming the main instrument of market orientation of a modern company and the criterion of its success, and is developing as a powerful scientific discipline.

Operational research methods are also a new area of quantitative methods in economic decision making. Among them are: linear and nonlinear programming, network planning, dynamic programming and the like. They are increasingly used in organizing the production and sales processes. Simulation of future, i.e. desired conditions, is increasingly appearing as one of the mathematical methods in the analysis and planning of company's development.

The wide application of these mathematical methods had specific effects on the development of business economics as a science. The economic efficiency of the 
Rajko MACURA

Banja Luka College

Banja Luka
Andrija BLANUŠA

Faculty of Social Sciences

Belgrade

application of these methods is conditioned by the knowledge of the economic essence of the problems of the companies that are solved by these methods. Excessive focus on the use of mathematical and statistical methods has led to a lag in the study of the economic essence of the processes and internal relations in the company. Therefore, the study of numerous methods often becomes a purpose to itself.

They are usually applied to hypothetical and theoretical cases instead of serving to solve the company's specific problems. (Kukoleča, 1965: 34)

In the sixties of the last century, there was a strong penetration of cybernetics in the management of reproduction processes in the company. "Information-feedback loop" is constructed in order to manage the dynamics of the organizational system (Forester, 1961: 17). In companies, this dynamic is determined by the input-output elements of the company's economy, as a special economic system. The interaction of these input-output elements is considered on the basis of statistically determined correlations in the dynamics of individual elements or components of the company. In this way, industrial dynamics is developed as a special scientific-methodological discipline, aimed at managing the behavior of a company as an economic system. In this model, the economic characteristics of the behavior of people (employees) are not sufficiently theoretically studied or scientifically and analytically viewed within the company.

Various fluctuations in the development of business economics as a science arise from an insufficiently clearly set goal, i.e. the goal function of that science. Partial methods of research of individual components (factors) or functions of the company - condition the diversity of partial goals and their incoherence. They can answer the question HOW to improve certain segments or phenomena in the company, its part, reproduction phase, etc., but do not provide complete scientific answers to questions of survival and development of the company as a complex economic, organizational and rational social system (subsystem). Various methods and techniques have led to partialization in the study of business economics as a scientific discipline.

Organizational research methods, and especially mathematical methods of operational research, decision theory, game theory, industrial dynamics - serve the business economics as an important research instrument, but in their essence and content are not included in the system of economic sciences. These methods often go beyond the economic essence of the company's problem and are reduced to management methods in the company's economy.

The development of organizational and other methods and techniques of business research has contributed to the perception of complexity and strong development of business economics as a scientific discipline in the conditions of industrialization, market environment and informatics. 
In the Republic of Serbia, with the abolition of the social concept based on the "system of associated labor" in the early 1990s, opportunities were created for deep social and economic transformations of the national economy and companies.

The changes that are reflected in the transformation of public property, returning to the company as the basic economic entity with ownership attributes, capital and profit, have created realistic conditions and preconditions for reaffirming the entrepreneurial concept of the business economics. To this day, business economics as a scientific discipline is based on these foundations.

Profit as the goal of the company's business results and the pursuit of its maximum economic efficiency - in terms of business success - are the essence of the entrepreneurial, market concept of business economics as a scientific discipline. (Živković, Ilić, Bevanda, 2014: 28)

The category of company is affirmed in terms of the basic economic subject of business. It implies economic and legal independence and business operations of the company in market conditions. The new concept abolishes the legal subjectivity of the organizational parts of the company.

Free performance of activities, concluding contracts and bearing risks in business - are prerequisites for the entrepreneurial concept of the company.

The risk of business and decision-making is borne by the entrepreneur, i.e. the management of the company, who also has full freedom to perform activities and make decisions.

The entrepreneurial concept in domestic practice has most deeply developed the economic character and functions of the company so far, as well as other economic and market categories: management, marketing, operational management, and others.

\section{The relationship between business economics and the organization of the company}

In the second half of the 20th century, the previous framework of cost theory (mostly by German authors) was expanded by post-war theorists of business economics, with the aim of adapting it to new, current social relations. In the same scientific discipline, a number of issues of organizational science are covered and processed.

This discipline extends the classical theory of costs to marginal costs, with the expansion of the framework of the business economics to the economic principles of reproduction, means of production (factors of production) and showing the 
Rajko MACURA

Banja Luka College

Banja Luka
Andrija BLANUŠA

Faculty of Social Sciences

Belgrade

production process in the company as an organizational phenomenon.

A detailed analysis of the organization of functions in the company is introduced into the theoretical framework of business economics.

This concept is focused on the economy of labor and resources, combining the factors of production in order to achieve maximum economic success and especially the costs of the company. In that way, a direct connection is established between the business decision and the business, i.e. economic result. A special place in conducting the business policy of the company belongs to the costs, i.e. the need for their constant analysis and reduction in the dynamics of the company's business.

In this theoretical approach, organizational issues are represented to the same extent as the issues of business economics. A special place in the study of this discipline is given to the new categories of "self-management" and "joint work". The company (work organization) is standardized and shaped as an economic and organizational subsystem in the system of self-management and joint work.

The economic issues of the company were studied, however, only in fragments, without connecting and rounding off the framework of the company as an economic and organizational unit.

In the normative system, i.e. the legal regulation of that period, the company does not represent an economic entity and a whole. The market dimension of the company is completely suppressed, and the role of the regulatory mechanism of the company is performed by para-state and para-economic institutions.

The concept of separate and parallel study of the business economics and the organization of the company is completely processed in the works of our famous authors PhD Stevan Kukoleča and PhD Živko Kostić (Kostić, 1977; Kukoleča, 1968).

This concept distinguishes organizational topics from the domain of business economics. Business economics is "a concrete economic reality that is expressed in certain conditions or in certain changes in those conditions, depending on the goals that are set for it."

In the business economics, the term "mesoeconomics" is introduced, as a systemic link between the economy of the individual (microeconomics) and the economy of society (macroeconomics) as a whole. The theoretical bases of investments and results caused by mutual relations in the dynamics of these economically connected and interdependent human and material components are investigated.

The goals of a company are conditioned by the role of a specific company in the state (national) economy, its size, technology and the like. Thus, set goals and connections between the economy of society and the economy of the company - set the basic determinants of the functioning of the company, as a relatively complete economic subsystem, but also the business economics as a special scientific discipline. This determined the framework and domain of its opus and research. 
The listed characteristics of the company refer to (Živković, Ilić, Bevanda, 2014: 25):

- goals,

- components,

- mutual relations of components,

- factors that condition mutual (internal) relations.

The goals of the business economics are aimed at studying those phenomena and factors that determine the results that contribute to the achievement of the goals of the companies as specific economic entities. These goals are:

a) Macroeconomic - based on the requirement that the results of specific production (or services) within the company provide optimal social reproduction and funds to cover social needs (general and joint consumption). These goals ensure the regulation of the company's obligations to the state.

b) Mesoeconomic - based on the requirement that the results of specific production or services of the company provide funds for the accumulation and further development of a given production or services in the company. Achieving these goals ensures survival and development, i.e. the requirements of growth and expansion of activities and functions of the company.

c) Microeconomic - which are reduced to the requirement that the company's results provide the means to maintain and increase the living standards of employees and improve their working conditions. These goals ensure the productivity of employees in the company, their motivation to work, the appropriate level of consumption and standard of living of employees and their families.

The components of company's economy, as a specific and concrete material organizational system, form its structure and represent an important subject of analysis and study of business economics.

These components appear as:

a) components of results - in the form of physical product, value of production, total income and profit, as a financial result, and

b) investment components - expressed as labor force, engaged means and assets, objects of labor and costs.

The process of reproduction of the company, as an object of observation and study of the business economics, refers to the economic transfer of the investment components into the components of results. The result of that transfer should be an increase in the newly created value of the company.

The mutual relations of the components of the economy are formed in the process of transforming the investment components into business results. These input-output relationships are specific to each particular company. They are 
Rajko MACURA

Banja Luka College

Banja Luka
Andrija BLANUŠA

Faculty of Social Sciences

Belgrade

subordinated to the goals of the company through the basic economic principle of the company's business: to achieve maximum results with minimum investments. Scientific analysis and theoretical elaboration of this principle represent, in addition to the above, one of the important contents of business economics as a scientific discipline.

Factors that determine the relationships and results in the company's economy are of objective and subjective nature. They operate within the company (internal) and from the environment (external). Differentiating the results of reproduction in the company according to these two criteria is significant from the point of view of the effects that economic practice can have from the achievements of the business economics.

Business economics, in the study of the connections between factors and the results of their actions - must separate what is organizational, i.e. subjective - from what is objectively given and more broadly conditioned.

The factors that affect the company are numerous and with different, often opposite effects. In the commodity-money economy, the influence of the market and technology is crucial, as well as the role of the state, through measures and instruments of economic policy. The most important internal factors in the company are: organization, labor force and means of production.

The newer development stage of business economics in theory and practice opens with the approach to business economics as a dynamic organizational system. The input-output components of that system appear as a quantitative category subject to economic measurements and interactions.

Theoretical concepts treat the organization, i.e. the company, as a system composed of parts that are in constant interaction and mutual communication. In this concept, it is important to establish and maintain horizontal connections and relationships between parts of the system, as well as to adapt the system to the requirements of the environment.

The organizational system provides a structure and relationships that will contain in one organizational unit of the company all the necessary functions and activities to perform the tasks of the subsystem - the company.

Business economics as an organizational system includes such a methodological approach that elaborates not only the connections and relations of the elements (factors) of the system, but also their relations with functionally connected companies and the environment. In this sense, business economics develops as a complex system composed of components: people, resources, organizations (as subsystems), their mutual connections and relationships. At the same time, it is an open and dynamic system, which includes the overall macro, meso and microorganizational structure of the company.

In addition to the development of management and operational research, the development of modern information technologies has conditioned the application of cybernetics in the company. In this way, the company is treated as a cybernetic 
system whose dynamics can be automatically regulated. The basis of this concept is the interactions between the input-output components of the company as a system, provided that they are evaluated on the basis of indicators of correlations related to the dynamics of individual elements in the process of company's business operation.

The change in the relationship between the output and input states of these elements in the time succession expresses the dynamics of the quality of the economy in those periods. All output and input changes are transformed into work equivalents, and a model is constructed in which all these quality changes are reduced to work, as a unique economic indicator. This creates new opportunities not only for econometric, but also cybernetic approach to the business system and business economics.

Modern qualitative and quantitative approach to the problems and phenomena of mesoeconomics is of great importance for the further development of the theory of business economics, as well as for the development of analytical bases for the preparation and shaping of various economic decisions in business practice.

\section{The relationship between business economics and other economic disciplines}

The company is the subject of observation and study of a large number of economic and non-economic scientific disciplines, such as (Živković, llić, Bevanda, 2014: 32):

- economics, as a general science that studies the processes and laws of social reproduction;

- scientific disciplines that study man at work: work psychology, work physiology, ergonomics, work sociology, etc.;

- economic-analytical and record-technical sciences such as: accounting, balance sheet analysis, statistics, cybernetics, etc.;

- technical-technological sciences, that study technical subsystems in the company, and others.

These and many other disciplines, in accordance with their own frameworks, goals and character, encompass and study certain dimensions, phenomena, processes and categories of companies.

Most scientific disciplines from the framework of economic sciences study companies, either directly or through general laws that reflect on its functioning, development and reproduction. The general economic science and basic scientific 
Rajko MACURA

Banja Luka College

Banja Luka
Andrija BLANUŠA

Faculty of Social Sciences

Belgrade

discipline is economics (previously studied as political economy). The economics is focused on the study of the laws of development of the material basis of society, methods of production and relations that arise and change depending on the development of productive forces, i.e. material basis.

Economics deals with relations in reproduction that are relevant to the reproduction of society as a whole. It studies the laws of production, exchange, distribution and consumption. Since they represent the stages of social reproduction, both (political) economy and business economics study the process of reproduction. The difference is in the level of study: economics as a fundamental scientific discipline studies social reproduction, and business economics studies the reproduction of the company as a mesoeconomic system.

In the study of flows, phenomena and laws, business economics is used and starts from the results and laws of economics, i.e. general knowledge of the economy as a whole.

Organization of the company as a science studies the company from the point of view of the process of organization, structure and the relationship of components, viewing it as a dynamic organizational system. Business economics and organization of the company as scientific disciplines study the phenomena, conditions and changes in conditions in the company. These two disciplines are very close, closely and firmly connected in the subject of study.

Business economics studies the company and its economy as a concrete economic reality, while the organization of the company studies the organizational aspects of the company's business, its components, connections and dynamics. It deals with the company and its functioning as a subject and result of the organizing process.

A special scientific discipline, organizational behavior, deals with the role of a man in the company in all aspects of his individual and collective work and behavior, as well as the mutual relations of a man and other components of the company.

Accounting and business economics are scientific disciplines that are also historically and substantively closely related. In its beginnings, business economics originated and developed from accounting, as a developed scientific discipline. According to the subject of study, which are the conditions and changes in conditions in the company, i.e. its components, these two disciplines are mutually conditioned and closely related. The efficiency of the business economics can neither be seen nor expressed without accounting indicators and statements.

Accounting and business economics differ in the content and methodology of the research. Business economics studies the reproduction of a company through: investments, results, relations between results and investments, quality factors of the economy and others. Accounting studies these categories from a specific angle: it quantitatively expresses their states and changes. It provides indicators for controlling the achievement of business results, making business decisions, profit distribution and the like. In that way, accounting and bookkeeping provide the 
company with control over work and management.

Business economics is also related to statistics, econometrics, cybernetics and other sciences that use quantitative research methods. Without modern quantitative research methods, it is difficult to accurately determine the state of certain phenomena and processes in the company and quickly make quality business decisions. Business economics uses these methods, such as: indices, samples, trends and the like. Statistical methods are universal and are used in various disciplines. The methods of business economics are specific, and their application in other scientific fields is limited.

Business economics is also connected with a number of non-economic scientific disciplines: social, technical, medical and legal. Some of these sciences study and capture certain aspects and categories of the company, while business economics studies all phenomena and processes in the company through the ratio of achieved results and investments made to achieve these results, i.e. through the business success of the company. Business economics uses the results of these researches in accordance with its goals and needs. These, in turn, contribute to a better and faster development of business economics as a scientific discipline and practical science.

\section{Conclusion}

Business economics provides economic instruments for efficient management and business operations of companies. It creates a theoretical basis and instruments for strategic and operational management of the company's economy. In this way, business economics creates the conditions for the development of a wider, branch or national economy and the satisfaction of a wide range of economic needs within and outside the company. In the course of these processes, the choice of directions for the future development of the company is important, having in mind the diversity of interests, external requirements and limitations. Through this study, preconditions are created for achieving the set goals of the company, in accordance with the available funds, i.e. resources.

Business economics studies the methods and techniques of business operations. Methods and techniques ensure the efficiency of the available components and resources of the company, as well as the optimal results of its business.

The goals and methods of business economics are aimed at finding optimal solutions for the realization of the company's tasks in conditions of limited resources and competition in the market.

Business economics encompasses the totality of economic interests or goals of the company, their qualitative and quantitative properties and mutual relations. It studies the efficiency and effectiveness of the functioning and development of the company as a business unit and business entity. By developing modern instruments and methods that can improve the business activities of companies 
Rajko MACURA

Banja Luka College

Banja Luka
Andrija BLANUŠA

Faculty of Social Sciences

Belgrade

in various spheres and areas, business economics undoubtedly contributes to local economic development, regional development, and the overall progress of modern companies and organizations.

\section{LITERATURE}

1. Afflerbach P; Bolsinger M. \& Röglinger M. (2016): An economic decision model for determining the appropriate level of business process standardization, Business Research, 9(2), pp. 335-375.

2. Ding X. Q; Zhang W. D. \& Hou, R. C. (2014): Research of discrete manufacturing industry production control system based on RFID technology, Advanced Materials Research, 926, pp. 1493-1496.

3. Živković Momčilo, Dragičević-Radičević Tatjana, Ilić Silvana, Bevanda Vuk (2007): Ekonomika poslovanja - praktikum, treće izmenjeno i dopunjeno izdanje; Beograd: Megatrend univerzitet.

4. Živković Momčilo, Ilić Silvana, Bevanda Vuk (2014): Ekonomika poslovanja, sedmo izmenjeno i dopununjeno izdanje; Beograd: Megatrend univerzitet.

5. Jovanović Petar (2013): Upravljanje investicijama; Beograd: VŠPM.

6. Jovetić Slavica (2015): Merenje performansi preduzeća; Kragujevac: Ekonomski fakultet.

7. Karapetrovic, S; Casadesús, M. \& Heras, I. (2006): Dynamics and Integration of Standardized Management Systems; Girona: Documenta Universitaria Serie Gitasp No. 1.

8. Canet-Giner M.T; Fernández-Guerrero R. \& Peris-Ortiz M. (2010): Changing the strategy formation process in a service cooperative, Journal of Organizational Change Management, 23(4), pp. 435-452.

9. Kostić Živko (1977): Osnovi teorije mezoekonomije; Beograd: Savremena administracija.

10. Kostić Živko (1977): Osnovi organizacije preduzeća; Beograd: Savremena administracija.

11. Kostić Živko, Milojević Miroslav (1996): Ekonomika preduzeća; Beograd: Institut za ekonomiku i finansije.

12. Kukoleča Stevan (1968): Ekonomika preduzeća; Zagreb: Informator.

13. Rakita Branko (2013): Međunarodni biznis i menadžment; Beograd: Ekonomski fakultet.

14. Sloman John, Garratt Dean, Guest Jon, Jones Elizabeth (May 9, 2016): Economics For Business, 7th edition; Philadelphia, Pennsylvania: Trans-Atlantic Publications, Inc.

15. Sloman John, Garratt Dean (2019): Essentials Of Economics, 8th New edition; United Kingdom: PEARSON. 
16. Todorut A. V; Cirnu D. \& Niculescu G. (2011): Management of business processes through reengineering, Proceedings of the 12th WSEAS international conference on Mathematics and computers in biology, business and acoustics in Transylvania University of Brasov, Romania in April 11-13, 2011, World Scientific and Engineering Academy and Society WSEAS Press, Bucharest, pp. 237-242.

17. Fouayzi H; Caswell, J. A. \& Hooker, N. H. (2006): Motivations of fresh-cut produce firms to implement quality management systems, Applied Economic Perspectives and Policy, 28(1), pp. 132-146.

18. Forester Jay W. (1961): Industrial Dynamics; Cambridge, Massachusetts: The M.I.T. Press, Massachusetts Institute of Technology.

19. Han S. B; Sim K. L. \& Ebrahimpour M. (2012): Relationships among ISO 9001, competitive dimensions and profitability, International Journal of Services and Operations Management, 11(2), pp. 222-236.

20. Chang W. J. A. \& Huang, T. C. (2010): The impact of human resource capabilities on internal customer satisfaction and organisational effectiveness, Total Quality Management, 21(6), pp. 633-648.

\section{WEBOGRAPHY:}

1. Banton Caroline: Business Economics, reviewed by Eric Estevez, updated Nov 27, 2020, https://www.investopedia.com/terms/b/business-economics.asp, accessed on: 29.1.2021.

2. Nageshwar Das: Business Economics; Definition, Nature, Scope, and Importance, published on March 29, 2021, https://www.ilearn/ot.com/business-economicsdefinition-nature-scope-and-importance/59475/, accessed on 30.3.2021.

3. Shraddha Sureka: Business Economics, reviewed By Dheeraj Vaidya, CFA, FRM, https:// www.wallstreetmojo.com/business-economics/, accessed 30.1.2021. 
Рајко МАЦУРА

Бања Лука Колеџ

Бања Лука
Андрија БЛАНУША

Факултет друштвених наука

Београд

\section{УЛОГА И ЗНАЧАЈ ЕКОНОМИКЕ ПОСЛОВАҢА У РАЗВОЈУ САВРЕМЕНИХ ПРЕДУЗЕЋА И ОРГАНИЗАЦИЈА}

Апстракт: Економика пословања спада у групу економских наука. Економика пословања је научна област која се бави пословањем предузећа у условима ограничених ресурса и тржишних законитости. У питању је сложена, свеобухватна дисциплина која изучава економска стања, економске процесе и економске односе у оквиру предузећа као привредног субјекта. У оквиру економике пословања се врши квалитативна и квантитативна анализа свих економских појава, категорија и односа у предузећу и његовом ширем економском и функционалном окружењу. У раду се изучава директан и индиректан утицај економике пословања на развој савремених предузећа и организација.

Кључне речи: ЕКОНОМИКА ПОСЛОВАҢА, КОМПАНИЈА, ПОСЛОВАҢЕ, ОРГАНИЗАЦИЈА, ЕКОНОМИЈА, МЕНАЏМЕНТ. 